DOI https://doi.org/10.30525/978-9934-26-047-6-33

\title{
БІОЛОГІЧНІ РИЗИКИ ВНУТРІШНЬОУТРОБНОЇ ІНФЕКЦІЇ
}

\author{
Жигульова Е. 0. \\ кандидат біологічних наук, доцент, \\ завідувач кафедри фізичної реабілітачії \\ та медико-біологічних основ фізичного виховання \\ Кам'янеиь-Подільський національний університет імені Івана Огієнка \\ м. Кам'янець-Подільський, Хмельнищька область, Украӥна
}

Здоров'я новонародженої дитини визначається станом здоров'я матері, особливостями перебігу вагітності та пологів, оптимальною організацією надання спеціалізованої медичної допомоги вагітним, породіллям та новонародженим [3, с. 30].

Однією з важливих та актуальних проблем сьогодення $є$ внутрішньоутробні інфекції (ВУІ) - група захворювань, за яких зараження відбувається від матері під час внутрішньоутробного розвитку плоду або під час пологів. У сучасній літературі зустрічається назва TORCHінфекція: T (toxoplasmosis - токсоплазмоз), R (rubeola - краснуха), C (cytomegalia - цитомегалія), H (herpetica infectio - герпетична інфекція), О (other - інші види інфекцій) [3, с. 30].

На сьогодні внутрішньоутробні TORCH-інфекції виявляються основним, фоновим або супутнім захворюванням в 70,05\% випадків перинатальних втрат. Дослідниками встановлено, що серед збудників TORCH-інфекцій у жінок під час вагітності найчастіше реєструються вірус простого герпесу $(70,23 \%)$, цитомегаловірус $(34,35 \%)$, токсоплазми $(30,53 \%)$. Основною причиною смерті недоношених дітей (після передчасних пологів), які померли у ранньому неонатальному періоді, зареєстровано ТORCH-інфекції у 60,7\% випадків, у дітей від термінових пологів - різноманітні вроджені вади розвитку $(85,7 \%)$ [1, c. 61$]$.

Вченими виявлено порушення неонатальної адаптації у новонароджених, народжених жінками 3 TORCH-інфекціями, реєструється більша частота дизадаптаційних синдромів та важчі їх прояви у дітей. [2, с. 76]. Тому актуальність розгляду питань небезпеки ВУІ не підлягає сумніву

3 кожним роком спостерігається зростання частоти ВУІ, що, очевидно, пов'язано, з одного боку, з більш інформативними та доступними методами діагностики; 3 іншого, - iз зростанням 
інфікованості жінок дітородного віку збудниками, що спричиняють внутрішньоутробні інфекції плоду [5, с. 64]. На сучасному етапі серед провідних збудників ВУІ у новонароджених виділяють віруси, бактерії, гриби, найпростіші, хламідії, мікоплазми, а саме:

I. Вiруси: цитомегаловірус, простий герпес I-II типу, вірус Ебштейн-Барра, вірус гепатиту, краснухи, кору, епідпаротиту, грипу, парагрипу, аденовірус, ентеровірус, РС-вірус;

II. Бактерії: лістерії, трепонема, мікобактерії Коха, умовнопатогенна флора (стрептококи, кишкова паличка, ентеробактерії).

III. Паразити - токсоплазма.

IV. Мікоплазми.

V. Хламідії.

ВУІ впродовж останніх років посідають провідне місце (1-3) в структурі причин смертності новонароджених, їм також належить суттєва роль у виникненні та розвитку багатьох патологічних станів ураження нервової системи, дисфункція органів та систем, що формуються в періоді дитинства, і навіть пізніше [4].

Інфікування плоду на певному етапі внутрішньоутробного розвитку має різний патологічний ефект, а саме, інфікування в ранні терміни вагітності (до 12 тижнів), в період, коли відбувається закладка органів та систем, формування зовнішніх частин тіла і внутрішніх органів, часто призводить до самовільного переривання вагітності, формування вроджених вад розвитку, мертво народження [4, с. 34]. Найчастіше, вроджені вади виникають під впливом вірусів (краснухи, кору, простого герпесу, вірусного гепатиту, грипу, респіраторних інфекцій) .

Дія несприятливих факторів (інфекції) в другій половині вагітності (після 24 тижнів), саме в період росту і дозрівання плоду, спричинює передчасне народження дитини 3 клінічними ознаками внутрішньоутробної інфекції, народження дітей з малою масою (менше 2000 г), вадами розвитку легенів, серця, мозку (гідро-, мікроцефалія) [5].

Ураження плаценти зумовлює розвиток фетоплацентарної недостатності, внаслідок чого створюються передумови для хронічної гіпоксії, гіпотрофії плоду, що призводить до зниження опірності дитячого організму, розвитку імунодефіцитного стану. Наслідками ураження плаценти й плоду, що можуть виникати на будь-якому терміні вагітності, можуть бути викидні, передчасні пологи, формування вроджених вад розвитку, антенатальна загибель плоду [3 с. 32].

Таким чином, наслідки ВУІ залежать від періоду інфікування i можуть бути такими:

- аборти, викидні, мертвонародження; 
- вади розвитку внутрішніх органів (нирки, легені, мозок тощо);

- неонатальна смерть;

- видужування;

- тривале перебування збудника в організмі дитини 3 подальшим розвитком серйозних захворювань (порушення мови, затримка психомоторного розвитку дитини, рухові порушення, хронічна патологія нирок, легенів) [4].

Розвиток перинатальної інфекції у новонароджених часто зумовлюють такі несприятливі чинники (фактори інфекційного ризику):

1. Обтяжений акушерський анамнез - викидні, мертвонародження, невиношування при попередніх вагітностях, народження дітей 3 множинними вродженими вадами розвитку або дітей, які померли в ранньому віці.

2. Патологічний перебіг даної вагітності - загроза переривання, багатоводдя, токсикози вагітних, передчасне відходження навколоплідних вод, передчасне відшарування плаценти або прирощення плаценти.

3. Урогенітальна інфекція, що є досить поширеною серед жінок дітородного віку. На сьогодні запальні гінекологічні захворювання бактеріально-вірусної етіології становлять близько 50\%, а бактеріальний вагіноз із глибокими порушеннями мікоекології генітального тракту трапляється у $34 \%$ вагітних. Гострі респіраторні вірусні інфекції під час вагітності [3, с. 62].

Дуже поширеним $є$ здорове носійство мікоплазм, хламідій, тобто коли між макро і мікроорганізмом встановлюються певні взаємовідношення - взаємотолерантність. Проте при зниженій опірності організму, стресах, ця флора активізується, що $є$ реальною загрозою, особливо для плоду [4; 5, с. 65-69].

4. Патологічний перебіг пологів - тривалий безводний період (більше 6 год.), брудні навколоплідні води, акушерська допомога при пологах.

5. Запальні інфекційні процеси, підвищення температури в матері до, під час і після пологів (ендометрит, мастит).

6. Народження дитини 3 такими клінічними ознаками: недоношеність, дуже мала маса при народженні, вроджені вади розвитку, гідроцефалія, дихальні розлади, жовтяниця, неврологічна симптоматика [4].

Отже, система мати-плід під час вагітності піддається безперервному впливу різних чинників навколишнього середовища. Під впливом цих агентів змінюється перебіг фізіологічних взаємовідносин 
між материнським організмом та плодом, в результаті чого досить часто виникають різні форми патології, в тому числі вроджені вади розвитку.

Висновок. Таким чином, перинатальні інфекції завжди мають серйозний прогноз для життя та здоров’я дитини. При ранньому виявленні та адекватному лікуванні ВУІ прогноз для життя, здебільшого, сприятливий; для повного видужання - сумнівний, оскільки після деяких перенесених інфекцій збудник часто персистує в організмі, спричинюючи різноманітні захворювання в майбутньому. А тому, здоров'я новонародженого передбачає обстеження жінки на етапі планування вагітності, обстеження та лікування вагітних жінок 3 високим інфекційним ризиком. Значна увага повинна приділятись пропаганді здорового способу життя населення та санітарнопросвітницькій роботі з населенням.

\section{Література:}

1. Васильєва Н.А., Геряк С.М., Жиляєв М.M. Вплив TORCHінфекцій на перебіг вагітності, передчасних, своєчасних пологів та перинатальну смертність плодів та дітей. Актуальні питання педіатрії, акушерства та гінекології. 2012. № 2. С. 60-62.

2. Знаменська Т.К., Лошак О.О., Дзязик Т.М., Килимник Т.М., Пятчанін С.Ю. Клінічна характеристика та особливості перебігу ранньої неонатальної адаптації при вродженій пневмонії у новонароджених від матерів з TORCH-інфекціями. Современная пед. 2015. № 8 (72). С. 74-77.

3. Сміян I.C., Павлишин Г.А. Проблеми внутрішньоутробних інфекцій та можливості їх вирішення на сучасному етапі. Ліки України. липень-серпень, 2008. №6 (122). С. 30-35.

4. Ткаченко Ю.П., Леженко Г.О., Резніченко Ю.Г., Резніченко Г.І. Внутрішньоутробні інфекції. Епідеміологія, клініка, діагностика та сучасні принципи терапії у вагітних жінок та дітей. 2012. 141 с.

5. Щербина М.О., Вигівська Л.А., Капустник Н.В. Внутрішньоутробні інфекції - причина патологічних станів перинатального періоду. Перинатология и педиатрия. 2016. №2 (66). С. 65-69. 